\title{
Academic Contact: A Theoretical Approach to Israel Studies in American Universities
}

\author{
Mohammad Ali Mousavi ${ }^{1}$ \\ Elham Kadkhodaee ${ }^{2}$
}

${ }^{1}$ Associate Professor, North American Studies, Faculty of World Studies, University of Tehran ${ }^{2} \mathrm{PhD}$ Candidate, North American Studies, Faculty of World Studies, University of Tehran Email: kadkhodaee@ut.ac.ir

\section{Doi:10.5901/mjss.2016.v7n4p}

\section{Abstract}

Israel studies courses and chairs have been proliferating in recent years in American universities, taught by American professors and visiting Israeli scholars. Such programs are funded and promoted by Israel advocates as a way of generating sympathy and enhancing understanding of Israel. On the other hand, the English fluency of particular Israeli scholars has enabled them to produce their academic output in English and become influential voices in their respective fields. Despite its significance, few academic studies of such programs and individuals have been carried out. Aiming to fill this lacuna, a case study of Israel studies courses and their instructors is carried out. The paper demonstrates that the academic arena is a space where Israel advocacy has turned to; a space that needs its specific tools and players. The study concludes that contact theory is an appropriate theoretical framework that can enhance the understanding of this phenomenon. Through Israel studies courses and their instructors, contact takes place between Israeli and American individuals and societies. This academic contact is not limited to the physical dimension, since in the academic context, knowledge production in the form of books and articles is itself an arena where ideas are presented and contact happens in the virtual dimension. This is why the concept of academic contact is suggested for describing this specific type of interaction and a new way of looking into how sympathy towards a political entity can be generated amongst the educated population of a second country.

Keywords: Contact theory, academic contact, Israel studies, the United States

\section{Introduction}

Whilst there has always been talk of the strong political relationship between America and Israel, the cultural and social dimensions of the relationship are often overlooked ${ }^{1}$. Universities are important playing fields for Israel advocates since they are the intersection of the general public with the elite; whilst students usually come from different backgrounds, they are training to become tomorrow's decision makers, opinion makers and leaders. Another reason why they pay special attention to universities is that criticism and questioning often starts from this realm. ("A Burning Campus? Rethinking Israel Advocacy at America's Universities and Colleges," 2012, p. 7).

The current article aims to answer the question of how Israel studies as an academic discipline is applied by Israel advocates to influence the way the regime is perceived by Americans.

The promotion of Israel studies courses, centers and chairs filled by Israeli and American scholars in American universities, which has steadily grown in previous years (M. Bard, 2008) and (Koren \& Fishman, 2015), can be viewed as the response of these advocates to the challenges that they have perceived in this realm. Israel studies as an academic field should also be viewed as a response to the perceived pro-Palestinian bias, or, at least, lack of academic and impartial discussion of Israel in Middle Eastern studies centers (M. G. Bard, 2004; Coalition, 2007; Koren \& Einhorn, 2010), . To this must be added the fact that Israel is quite different to other area studies courses in the US which are usually funded by the government, in that they are mostly funded by private donors and organizations.

\section{Literature Review}

All the mentioned facts make Israel studies an interesting and exceptional case of area studies, but despite this, few

1 See (Bar-Siman-Tov, 1998; Ben-Zvi, 1993; Guerlain, 2010; Mearsheimer \& Walt, 2007) for a discussion of the relationship based on strategic factors and role of the lobby, and the works of Camille Mansour (1989), Jonathan Rynhold (2015), and (Bailyn, 2007; Mart, 2007; Thomas, 2007) who have more of a socio-cultural approach. 
academic endeavors into understanding this case have been attempted. Most analysis of Israel studies in American universities have been carried out by organizations and people who are themselves Israel advocates, and with the aim of identifying success and shortcomings and of fomenting better policy for the future. Annette Koren, for example, has published reports and directories on the state of Israel studies in America for Brandeis University's Maurice and Marilyn Cohen Center for Modern Jewish Studies, discussing its growth and the effectiveness of used strategies and methods to promote it, such as visiting Israeli professor programs and the Summer Institute for Israel Studies (Koren \& Einhorn, 2010; Koren \& Fishman, 2015; Koren \& Fleisch, 2014; Koren, Samuel, Aronson, et al., 2013; Koren, Samuel, Boxer, \& Aitan, 2013). Miriam Shenkar is another scholar who addresses the topic in her book entitled The Politics of Normalization: Israel Studies in the Academy (Shenkar, 2010). She compares the normalizing of Israel studies to Jewish studies, area studies and African American studies in the American academia. Addressing the question of why Israel studies is located outside Middle Eastern studies, she explains the placing of Israel studies chairs and centers using the concept of identity. Shenkar also applies a qualitative methodology, carrying out four case studies to examine the dilemma of "teaching the conflicts" within Israel studies.

Alek Epstein is another scholar who has worked on the subject of Israel studies. Whilst maintaining that the Israeli socio-political experience has been a unique one, he conducts a comparative analysis of the development of Israel studies in Israel/USA and Russia. (Epstein, 2004)

In an article entitled The Role of The Academic Man as A Cross-Cultural Mediator, the author uses some aspects of Allport's contact hypothesis to analyze the cultural role of visiting Fulbright professors, asserting that: "Interactions within the university systems occur in a social setting of formalized authoritative control, thus lessening the possibility of early tensions or misunderstandings being overtly expressed and disrupting the relationships." (Gullahorn \& Gullahorn, 1960, p. 415). But in this article the main theoretical framework is not contact theory, which is understandable since the theory was only a minor hypothesis at that time and had not expanded to what it is now.

The current paper proposes that contact theory which is a subcategory of social psychology, could be used as theoretical framework for better understanding Israel studies in American universities.

\section{Academic contact as a Theoretical Approach to Israel Studies in American Universities}

\subsection{Contact Theory}

The intergroup contact theory ${ }^{2}$ asserts that "intergroup contact under certain prerequisite conditions promotes the development of more harmonious intergroup relations." (Gaertner, Rust, Dovidio, Bachman, \& Anastasio, 1994, p. 492). "Equal status between the groups, ...cooperative intergroup interaction, opportunities for personal acquaintance between outgroup members, and norms within and outside of the contact setting that support egalitarian intergroup interaction" are some of the necessary conditions (Ibid). Later scholars have added other conditions to the original four. The rising number of prerequisite conditions is one of the major flaws of Allport's theory, since many more conditions could be added with no end in sight (Pettigrew, 1998), and such loosely related factors threaten the structural integrity of the theory (Gaertner et al., 1994). Another problem is that such focus on prerequisite conditions makes contact hypothesis a theory of when contact improves intergroup relations rather than how and why this happens; in other words, the "processes by which contact changes attitudes and behavior" are neglected (Pettigrew, 1998, p. 70). Pettigrew suggests "a broader theory of intergroup contact" in which the deficiencies that he highlights are resolved. In this broader theory, "learning about the outgroup, changing behavior, generating affective ties, and ingroup reappraisal ${ }^{3 "}$ are the processes that change attitude through contact (Ibid).

Addressing the issue of generalizability of interpersonal effects to intergroup relations, which questions whether contact and improved relations with an individual from a specific outgroup can lead to better attitudes towards the outgroup in general, Pettigrew points out that researchers propose two seemingly contradictory solutions: a salient categorization strategy and decategorization strategy. But what he proposes is the sequential application of both strategies: "Diminished saliency of group categories can be important when intergroup contact is initiated. Once established, salient group categorization is required for the effects to generalize to the intergroup level"(Ibid, p. 75).

\footnotetext{
2 Gordon Allport has been credited as the developer of the hypothesis

${ }^{3}$ Ingroup reappraisal happens when ingroup members realize that their "norms, customs and lifestyle are not "inherently superior to those of outgroups" (Spears \& Tausch, 2012)
} 


\subsection{Israel studies}

To apply contact theory to Israel studies in American universities means that America and Israel are considered as two different groups with their own members, between which a degree of bias and prejudice exists. Contact theory proposes that through the four processes named, contact between members of these different groups can reduce this prejudice.

Israel faces potential prejudice and bias for two reasons. First is the fact that belonging to different groups, in and itself creates prejudice. The "mere-categorization " effect, according to social identity theory, suggests that "the mere act of categorizing individuals into groups made people think of themselves and others in terms of "us" and "them", and was sufficient to induce them to behave differently towards ingroup and outgroup members." (Ellemers \& Haslam, 2012, p. 380). So members of any two groups are biased against each other because of the fact that they are different. The second reason is more specific to Israel and is related to its problematic founding, and also the continued conflict with Palestinians and its Arab neighbours and the inability to reach peace. This is why, more than any other different group, Israel needs to construct narratives and discourses that provide it with legitimacy and portray it as a normal nation-state.

\subsection{Methodology}

The main methodology of the current research will be case study; specific Israel studies programs and courses and influential institutions, American Israeli scholars, and visiting professors programs, will be chosen and studied. The choice will inevitably be a selective one, but it has been tried to identify the cases that are most prominent and that fit the overall theme of the work. To remain more focused and systematic, data is confined to courses offered by Israel studies centers in American universities in the fall 2015 semester. Information on the courses and their instructors is obtained mainly through the websites of the respective centers and universities.

A case study is used in this research to answer descriptive or explanatory questions ("how and "why" questions), and where a close and first-hand understanding of a particular situation is needed (Yin, 2006). Yin also defines case study as "an empirical inquiry that investigates a contemporary phenomenon in depth and within its real-life context, especially when the boundaries between phenomenon and context are not clearly evident" (2009, p. 34). This makes the method suitable for this article, since the main goal here is to explain how the discipline of Israel studies contributes to the construction of a positive image of Israel for Americans. Another feature of case study that makes it suitable for the current research is its ability to provide a comprehensive and holistic view of complex human and social systems (Gagnon, 2010). In other words, case study "makes it possible to observe and analyze phenomena as a single, integrated whole" (Ibid, p. 1).

In discussing the factors that have contributed to the rising popularity of case-based approaches in the social sciences, Gerring points to the realist criticism of the "positivist" model of explanation, which claims that "causal mechanisms" as well as "causal analysis" should be payed attention to (Gerring, 2007). In other words, case study has become more popular with the shift from positivist and quantitative methods to postmodernism and qualitative methods (Gagnon, 2010).

\subsection{Israel studies centers}

According to the Jewish Virtual Library, currently there are 15 centers for Israel studies across American universities (Table 1), and 21 permanent and visiting chairs ${ }^{4}$. Tables 2-10 provide a list of Israel studies courses offered in the fall 2015 semester by these universities, along with the names of the instructors. According to the Israel Studies Directory: 2013-14, in the 2013-14 academic year, 730 Israel-focused courses and 1,123 Israel-related courses were taught at the 316 institutions analysed in the directory (Koren \& Fishman, 2015).

\footnotetext{
${ }^{4}$ http://www.jewishvirtuallibrary.org/jsource/isdf/chairs.html
} 
Table 1: Israel Studies Centers in American Universities

\begin{tabular}{|l|l|l|}
\hline No. & Center & University \\
\hline $\mathbf{1}$ & Center for Israel Studies & American University \\
\hline $\mathbf{2}$ & Schusterman Center for Israel Studies & Brandeis University \\
\hline $\mathbf{3}$ & Modern Jewish \& Israel Studies & Cal State University, Chico \\
\hline $\mathbf{4}$ & Institute for Israel \& Jewish Studies & Columbia University \\
\hline $\mathbf{5}$ & Institute for the Study of Modern Israel & Emory University \\
\hline 6 & Henry and Marilyn Taub Center for Israel Studies & New York University \\
\hline $\mathbf{7}$ & Crown Family Center for Jewish \& Israel Studies & Northwestern University \\
\hline $\mathbf{8}$ & Mirokowski Visiting Scholars Program in Israel Studies & Temple University \\
\hline $\mathbf{9}$ & Program on Israeli Law, Economy \& Society & UC, Berkeley \\
\hline 10 & Younes \& Soraya Nazarian Center for Israel Studies & UCLA \\
\hline 11 & Program in Jewish Studies & University of Colorado, Boulder \\
\hline 12 & Institute for the Study of Israel in the Middle East & University of Denver \\
\hline 13 & Joseph \& Alma Gilderhorn Institute for Israel Studies & University of Maryland \\
\hline 14 & Schwalb Center for Israel \& Jewish Studies & University of Nebraska, Omaha \\
\hline 15 & Israel Studies Collaborative Schusterman Center for Jewish Studies & University of Texas, Austin \\
\hline
\end{tabular}

\subsubsection{Overall observations}

As the tables demonstrate, a wide and diverse range of courses are offered as part of Israel studies programs. Issues such as literature, art, cinema, media, multiculturalism, etc. are covered (for example, Love, Sex, and Power in Israeli Culture (Table 5) and Multicultural Israel (Table 8)). While these issues are not always completely separated from politics, they provide a multifaceted knowledge of Israeli society, just as prescribed by surveys and reports published by pro-Israel institutions, aiming to change the perception that Israel is all about conflict. But this does not mean that more explicit political issues are neglected. The Israeli Palestinian conflict, Israel's relationship with America, and its internal politics are covered as well (The Israeli/Palestinian Conflict: Fundamental Questions (Table 6), U.S. Israel Relations (Table 3), State and Religion in Israel (Table 8)). This means that through providing all the necessary knowledge on Israel, whether cultural, social or political, Israel studies programs ensure that they define the academic discourse on Israel.

The analysis also demonstrates that the overall leaning of the courses in different universities are far from identical. Whilst some centers are more evidently and manifestly pro-Israel(see below), others are apparently more neutral, in some cases focusing mostly on literature and teaching the Hebrew language (University of Colorado Boulder, Program in Jewish Studies is one such example, demonstrated in Table 7). Koren uses a useful categorization that can be applied here: Israel-focused and Israel-related courses, where the former refers to courses "dealing specifically with Israel for the bulk of class time", and the latter to those that "offer more limited discussion of Israel" (Koren \& Fishman, 2015, p. 1). According to this classification, the University of Colorado's courses are mostly Israel-related rather than Israel-focused.

This is while some of these institutes such as The Berkeley Institute for Jewish Law and Israel Studies provides four courses, three of which promote an evidently positive image of Israel in the title of the course or its description. The courses are: Special Topics in Jewish Studies: A Jewish and Democratic State; Advanced Interdisciplinary Studies: Governance Feminism, and Innovation; and Entrepreneurship in Israel. The first course tackles one of the most serious challenges to Israel's image: the contradiction between the Jewish and democratic nature of the regime, and, as the title suggests, claims that the two are in fact compatible. The instructor of this course, Ori Aronson, is a founding member of the Center for Jewish and Democratic Law5, an institution that again emphasizes the compatibility between the two traits.

The second course also points to positive facts about Israel. The course description on the website reads: "Case studies will include Israel's sexual harassment legislation and its successful anti-trafficking campaign".

The third title is quite self-evident; innovation and entrepreneurship, concepts loved and respected by Americans. The course features "guest speakers, including various venture capitalists, innovators, CEO's, and academics"6.

\footnotetext{
${ }^{5}$ According to his bio on the Berkeley Institute for Jewish Law and Israel Studies website at: https://www.law.berkeley.edu/centers /berkeley-institute-for-jewish-law-and-israel-studies/people/visiting-faculty/ori-aronson/. No further information on this center could be obtained through the web.

6 It should be acknowledged that an objective and accurate assessment of the courses and programs would require actual presence in such courses, or at least surveys conducted on participants, which is unfortunately impossible with the current situation of American studies in Iran. The data available for the current study consist almost completely of that which+9h is obtainable through the web.
} 

neutral.

Most courses meanwhile are in the middle of the described spectrum, neither manifestly pro-Israel nor completely

Israel studies courses in many instances might not have an overtly pro-Israel substance, they might even be apolitical, or critical of certain Israeli institutions and policies, but the overall effect is normalizing and legitimising Israel through presenting it as an ordinary country with its own faults and merits, just as any other society or country.

The concept of democracy is one instance where this normalizing effort is evident. The syllabi and titles of some of the courses offered by these scholars demonstrate this normalizing effort. Yoram Peri (Table 8), Director of the Joseph and Alma Gildenhorn Institute for Israel Studies, the University of Maryland at College Park, for example, offered a course at American University entitled Israeli Democracy at 60: Achievements and Challenges in 2008. As the title suggests and the syllabus further explains, Israel has experienced both development and challenges such as the inability to reach peace, have a written constitution, and a clear definition of their collective identity, putting Israeli politics "at a crossroads" (Peri, 2008, p. 1). Nevertheless, the unquestionable fact is that Israel is a democracy.

In another course, Democracy in Theory and Israel in Practice, presented by Dana Blander at Tufts University in 2010, and listed in the Jewish Virtual Library's collection of syllabi on Israel studies ${ }^{7}$, it is stated that there are "inherent tensions and paradoxes" in democracy, and Israel is no exception (Blander, 2010, p. 1).

So as these examples demonstrate, Israeli scholars admit that Israel is not a perfect democracy, whilst at the same time claiming that this is not an abnormality. They either imply that there is no such thing as a perfect democracy in practice, or even in theory, making Israel similar to other democracies, or that there are shortcomings in the Israeli political system that are natural due to its security considerations. These shortcomings should be acknowledged together with the accomplishments of Israel, but they do not make it an outsider to the category of democracies.

Table 2: The Berkeley Institute for Jewish Law and Israel Studies Fall 2015 courses $^{8}$

\begin{tabular}{|l|l|l|l|}
\hline No. & lourse & Instructor & Position and Education \\
\hline 1 & $\begin{array}{l}\text { Special Topics in Jewish Studies: A } \\
\text { Jewish and Democratic State }\end{array}$ & $\begin{array}{l}\text { Ori Aronson } \\
\text { Bar-Ilan University Faculty of Law }\end{array}$ & $\begin{array}{l}\text { Israel Institute Visiting Professor/The Rosalinde } \\
\text { and Arthur Gilbert Foundation Visiting Professor of } \\
\text { Israeli Law and Society, }\end{array}$ \\
\hline 2 & $\begin{array}{l}\text { Advanced Interdisciplinary Studies: } \\
\text { Governance Feminism }\end{array}$ & $\begin{array}{l}\text { Hila Shamir (Tel Aviv University } \\
\text { Faculty of Law) }\end{array}$ & Israel Institute Visiting Professor \\
\hline 3 & $\begin{array}{l}\text { The Emergence of the Modern } \\
\text { Jerusalem, 1850-1950 }\end{array}$ & $\begin{array}{l}\text { Yuval Ben Bassat (University of } \\
\text { Haifa) }\end{array}$ & Berkeley Institute Visiting Professor \\
\hline 4 & $\begin{array}{l}\text { DeCal: Innovation and } \\
\text { Entrepreneurship in Israel }\end{array}$ & $\begin{array}{l}\text { Berkeley Institute Undergraduate } \\
\text { Fellows Nir Maoz }\end{array}$ & \\
\hline
\end{tabular}

Table 3: Center for Israel Studies, American university ${ }^{9}$

\begin{tabular}{|l|l|l|l|}
\hline No. & Instructor & Positions and education \\
\hline 1 & History of Israel & $\begin{array}{l}\text { Michael } \\
\text { Brenner10 }\end{array}$ & $\begin{array}{l}\text { Seymour and Lillian Abensohn Chair in Israel Studies } \\
\text { started Germany's first Jewish history and culture program } \\
\text { Studied in Heidelberg and Jerusalem, received his PhD in Jewish history from Columbia } \\
\text { University } \\
\text { Has taught at Indiana University, Brandeis, Stanford, Johns Hopkins, University of } \\
\text { California-Berkeley, the University of Haifa, the Central European University of Budapest, } \\
\text { and l'École des hautes études in Paris } \\
\text { the Ina Levine Invitational Scholar Fellow at the United States Holocaust Memorial Museum }\end{array}$ \\
\hline 2 & Negotiating Peace & Guy Ziv11 & $\begin{array}{l}\text { Writes in Assistant Professor, School of International Service } \\
\text { Director, Summer Abroad in Israel Program }\end{array}$ \\
& & $\begin{array}{l}\text { Faculty Affiliate, Center for Israel Studies } \\
\text { American educated } \\
\text { Has worked at the U.S. Department of State, , and for leading non-profit organizations } \\
\text { that promote American involvement in Israeli-Palestinian peacemaking } \\
\text { Israeli and American newspapers }\end{array}$ \\
\hline
\end{tabular}

\footnotetext{
${ }^{7}$ http://www.jewishvirtuallibrary.org/jsource/isdf/syllabitoc.html

${ }^{8}$ https://www.law.berkeley.edu/centers/berkeley-institute-for-jewish-law-and-israel-studies/courses/

${ }_{9} \mathrm{http}: / /$ www.american.edu/cas/israelstudies/courses.cfm

10 http://www.american.edu/cas/news/michael-brenner-abensohn-endowed-chair.cfm

11 http://www.american.edu/sis/faculty/ziv.cfm
} 


\begin{tabular}{|l|l|l|l|}
\hline 3 & $\begin{array}{l}\text { Politics and Public } \\
\text { Policy in Israel }\end{array}$ & Dan Arbell & $\begin{array}{l}\text { Scholar in Residence, Israel Studies } \\
\text { a 25 year veteran of the Israeli Foreign Service (with a long list of places where he has } \\
\text { served) }\end{array}$ \\
\hline $\mathbf{4}$ & $\begin{array}{l}\text { The Jewish World } \\
\text { after 1945 }\end{array}$ & $\begin{array}{l}\text { Michael } \\
\text { Brenner }\end{array}$ & Seymour and Lillian Abensohn Chair in Israel Studies \\
\hline $\mathbf{5}$ & $\begin{array}{l}\text { U.S. Israel } \\
\text { Relations }\end{array}$ & Guy Ziv & Assistant Professor, School of International Service \\
\hline
\end{tabular}

Table 4: Younes \& Soraya Nazarian Center for Israel Studies, UCLA

\begin{tabular}{|c|c|c|c|}
\hline No. & Course & Instructor & Positions and Education \\
\hline 1 & $\begin{array}{l}\text { Survey Of Middle East, 500-Present: } 500 \text { - } \\
1300\end{array}$ & $\begin{array}{l}\text { Michael } \\
\text { Morony }\end{array}$ & $\begin{array}{l}\text { Educated in US, proff. Of history, interest in Near Eastern History } \\
\text { (found no link to Israel) }\end{array}$ \\
\hline 2 & $\begin{array}{l}\text { Judaism, Christianity, And Islam: Comparative } \\
\text { Approach }\end{array}$ & $\begin{array}{l}\text { Reinhard } \\
\text { Krauss }\end{array}$ & \\
\hline 3 & Modern Israeli Literature Made Into Film & Lev Hakak & $\begin{array}{ll}- & \text { Educated in Israel and US } \\
\text { - } & \text { Member of American and Israeli Bar } \\
\text { 1976-Present - Professor, Hebrew Language and } \\
\text { Literature, University of California, Los Angeles } \\
\text { Has tought at American universities, and Israeli schools } \\
\text { and universities } \\
\text { - } \quad \text { Editor of Hadoar, The Hebrew Quarterly of America }\end{array}$ \\
\hline 4 & $\begin{array}{l}\text { Changing Narrative: Identity, Protest, And } \\
\text { Hope In Israeli Visual Culture }\end{array}$ & A. Gilboa & \\
\hline 5 & Elemntry Std Arabic & & \\
\hline 6 & Intermed Std Arabic & & \\
\hline 7 & Advanced Arabic & & \\
\hline 8 & Elementary Hebrew & & \\
\hline 9 & Intermediate Hebrew & & \\
\hline 10 & Advanced Hebrew & & \\
\hline
\end{tabular}

Table 5: Schusterman Center for Israel Studies Brandeis University

\begin{tabular}{|c|c|c|c|}
\hline No. & Course & Instructor & Positions and Education \\
\hline 1 & $\begin{array}{l}\text { Breaking Boundaries in } \\
\text { Contemporary Israeli Art }\end{array}$ & $\begin{array}{l}\text { Gannit Ankori } \\
\text { and llana } \\
\text { Szobel0 }\end{array}$ & \\
\hline 2 & Israel's Foreign Policy & Uri Bialer & $\begin{array}{l}\text { Visiting Professor in the Schusterman Center for Israel Studies and the } \\
\text { Departments of History and Near Eastern \& Judaic Studies, educated in Israel } \\
\text { and UK }\end{array}$ \\
\hline 3 & Myra Kraft Seminar in Israel & Randall S. Geller & $\begin{array}{l}\text { Educated in US, PhD from Brandeis, has taught at Brandeis University, } \\
\text { American University, and the University of Texas at Austin, the inaugural Les } \\
\text { and Eva Erdi Lecturer in Israel and Middle East Studies at ACJC (Australia) }{ }^{12}\end{array}$ \\
\hline 4 & $\begin{array}{l}\text { Ideology and Society in } \\
\text { Contemporary Israel: Major } \\
\text { Controversies }\end{array}$ & Uri Bialer & \\
\hline 5 & $\begin{array}{l}\text { Who is a Jew? Jewish Status } \\
\text { and Identity in Israel and } \\
\text { America }\end{array}$ & David Ellenson & $\begin{array}{l}\text { American rabbi and academic, a leader of the Reform movement in Judaism } \\
\text { Chancellor Emeritus of Hebrew Union College-Jewish Institute of Religion }\end{array}$ \\
\hline 6 & $\begin{array}{l}\text { Modern Arab-Jewish } \\
\text { Literature }\end{array}$ & Aviv Ben-Or & Doctoral student at Brandeis, \\
\hline 7 & $\begin{array}{l}\text { Love, Sex, and Power in } \\
\text { Israeli Culture }\end{array}$ & Ilana Szobel & $\begin{array}{l}\text { Educated in Israel and US (PhD New York Uni.) } \\
\text { Associate Professor on the Joseph H. and Belle R. Braun Chair in Hebrew } \\
\text { Literature }\end{array}$ \\
\hline
\end{tabular}

12 This means that those educated at American Israel studies programs can then be sent to other countries to promote the pro-Israel discourse 


\begin{tabular}{|l|l|l|l|}
\hline 8 & Jewish Political Thought & Yehudah Mirsky & $\begin{array}{l}\text { Associate Professor of Near Eastern and Judaic Studies and the Schusterman } \\
\text { Center for Israel Studies } \\
\text { studied at Yeshivat Har Etzion and Yeshiva College and received rabbinic } \\
\text { ordination in Jerusalem, } \\
\text { MA and PhD in US (Yale and Harvard) } \\
\text { worked in Washington as an aide to Senators } \\
\text { worked at winep } \\
\text { Served in the Clinton Administration } \\
\text { From 2002-2012 lived in Israel and was a fellow at the Van Leer Institute and } \\
\text { Jewish People Policy Institute } \\
\text { Writes in American and Israeli publications } \\
\text { Author of Rav Kook } \\
\text { Mystic in a Time of Revolution, Yale University Press, which is bio on "The first } \\
\text { chief rabbi of Jewish Palestine and the founding theologian of religious } \\
\text { Zionism"13 }\end{array}$ \\
\hline $\mathbf{9}$ & $\begin{array}{l}\text { Israeli Politics In Comparative } \\
\text { Perspective }\end{array}$ & Liora S. Norwich & $\begin{array}{l}\text { Ph.D. in Political Science at the Hebrew University of Jerusalem } \\
\text { Brandeis University, Schusterman Center for Israel Studies, Post-Doc }\end{array}$ \\
\hline $\mathbf{1 0}$ & $\begin{array}{l}\text { Making New Jews: Zionism } \\
\text { and the Construction of Israeli } \\
\text { Identity }\end{array}$ & Karen Spira & \\
\hline
\end{tabular}

Table 6: University of Maryland, Joseph \& Alma Gildenhorn Institute for Israel Studies, offered courses ${ }^{14}$

\begin{tabular}{|c|l|}
\hline No. & Course \\
\hline $\mathbf{1}$ & The Israeli/Palestinian Conflict: Fundamental Questions \\
\hline $\mathbf{2}$ & Special Topics in Israel Studies; Israel and the Arab Spring \\
\hline $\mathbf{3}$ & Special Topics in Israel Studies; Representing the Holocaust \\
\hline $\mathbf{4}$ & Investigating Topics in Israel Studies; Politics of Nation Building \\
\hline $\mathbf{5}$ & Investigating Topics in Israel Studies; Theories of Immigration: Israel as a Case Study \\
\hline $\mathbf{6}$ & Investigating Topics in Israel Studies; Beyond Black and White: Jews and Representations of Race \\
\hline $\mathbf{7}$ & Seminar in Israel Studies; Israeli Politics \\
\hline $\mathbf{8}$ & Seminar in Israel Studies; Introduction to Human Rights in Israel \\
\hline $\mathbf{9}$ & Advanced Topics in Israel Studies; Critical Issues in Israeli Cinema \\
\hline
\end{tabular}

Table 7: Faculty of Joseph \& Alma Gildenhorn Institute for Israel Studies

\begin{tabular}{|c|c|c|}
\hline No. & Name & Positions and Education \\
\hline 1 & $\begin{array}{l}\text { Sheila } \\
\text { Jelen }\end{array}$ & $\begin{array}{l}\text { Department of English and Jewish Studies Program } \\
\text { American Jewish Literature, The Literature of the Holocaust, Modern Hebrew Literature, Gender and Jewish } \\
\text { Literature, an Introduction to Jewish Literature } \\
-\quad \text { fellow at the University of Pennsylvania's Center for Advanced Jewish Studies } \\
\text { - } \quad \text { educated in US }\end{array}$ \\
\hline 2 & Yoram Peri & 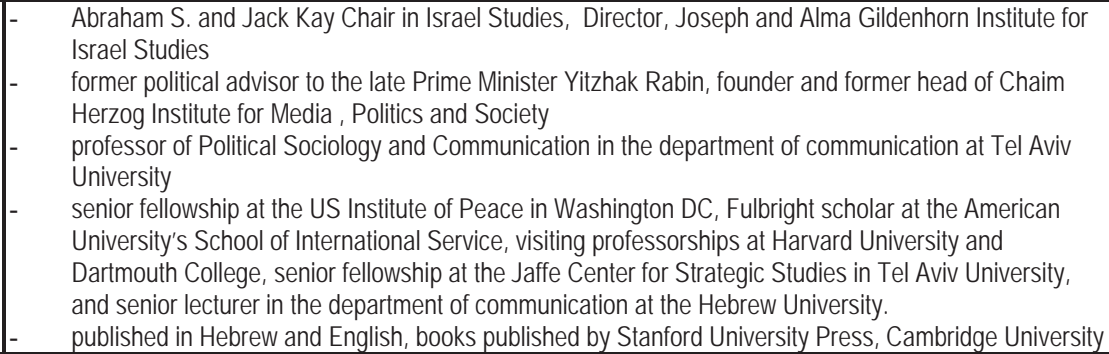 \\
\hline
\end{tabular}

13 http://yalepress. yale.edu/book.asp?isbn=9780300164244

14 Names of the instructors for these courses were not offered, so the names of the offered courses, and faculty members had to be presented in two different tables 


\begin{tabular}{|c|c|c|}
\hline & & $\begin{array}{l}\text { Press, and the United States Institute of Peace } \\
\text { president of the Association of the editors of Israel's Daily Newspapers and a member of the Press } \\
\text { Council. } \\
\text { Page on Israel embassy in US website, as speaker on "Israel in the media" at: } \\
\text { http://www.israelemb.org/washington/Speakers-Guide/Media/Pages/Yoram-Peri.aspx } \\
\text { Educated in UK and Israel, born in Israel, }\end{array}$ \\
\hline 3 & $\begin{array}{l}\text { Paul } \\
\text { Scham }\end{array}$ & $\begin{array}{l}\text { Visiting Assistant Professor of Israel Studies, Executive Director, Joseph and Alma Gildenhorn Institute } \\
\text { for Israel Studies } \\
\text { has worked on issues relating to Israel and the Israeli-Palestinian conflict for more than twenty years at } \\
\text { NGO's, in think tanks, and at universities } \\
\text { From 1996-2002, he lived in Jerusalem and, as a Research Fellow at the Truman Institute for the } \\
\text { Advancement of Peace of the Hebrew University } \\
\text { spent considerable time in Jordan and closely observed the failure of Jordanian "normalization" with } \\
\text { Israel } \\
\text { a Visiting Scholar at George Washington University and subsequently an Adjunct Scholar at the Middle } \\
\text { East Institute }\end{array}$ \\
\hline 4 & Eric Zakim & \begin{tabular}{|ll} 
& Professor of Hebrew Language and Culture \\
- & teaches courses in Hebrew Language and Israeli culture \\
a core faculty member at the Meyerhof Center for Jewish Studies and the Gildenhorn Institute for Israel \\
Studies \\
American educated
\end{tabular} \\
\hline \multirow[t]{5}{*}{\begin{tabular}{|l|}
$\begin{array}{l}\text { Visiting } \\
\text { profs }\end{array}$ \\
\end{tabular}} & $\begin{array}{l}\text { Ariel } \\
\text { Bendor }\end{array}$ & $\begin{array}{l}\text { Distinguishing Visiting Professor at the Joseph and Alma Gildenhorn Institute for Israel Studies and the } \\
\text { Francis King Carey School of Law, University of Maryland } \\
\text { Professor at the Bar-llan University Faculty of Law in Israel } \\
\text { Head of the Center for Media and Law and the Director of the Faculty of Law Publishing House at Bar- } \\
\text { Ilan University and the Chairperson of the sub-committee for law of the Israeli Council of Higher } \\
\text { Education } \\
\text { Was Visiting prof at Yale Law School } \\
\text { Israel educated }\end{array}$ \\
\hline & \begin{tabular}{|l|l} 
Adi \\
Mahalel
\end{tabular} & $\begin{array}{l}\text { Visiting Assistant Professor of Yiddish Studies } \\
\text { Educated in Israel and US }\end{array}$ \\
\hline & Pnina Peri & $\begin{array}{l}\text { senior lecturer in the department of liberal arts of Sapir Academic College (Hof Ashkelon, Israel) and in } \\
\text { Levinsky Teachers' training College } \\
\text { specialist in multicultural theories, gender, the political economy of education, social and cultural } \\
\text { aspects of the Arab-Israeli conflict, and cross culture communications } \\
\text { UK educated }\end{array}$ \\
\hline & $\begin{array}{l}\text { Sandra } \\
\text { Scham }\end{array}$ & $\begin{array}{l}\text { taught at Jerusalem University College and was an associate curator at the Pontifical Biblical Institute } \\
\text { in Jerusalem } \\
\text { coordinated academic exchanges on heritage conservation in Israel and Palestine under the Wye River } \\
\text { People to People Program of the US State Department } \\
\text { faculty of the Akko World Heritage Conservation Project in Israel, and she is also currently working as } \\
\text { an American Association for the Advancement of Science Fellow in the Asia and Middle East Bureaus } \\
\text { of USAID } \\
\text { US educated }\end{array}$ \\
\hline & \begin{tabular}{|l} 
Daniel \\
Zisenwine
\end{tabular} & $\begin{array}{l}\text { Visiting Assistant Professor of Israel Studies } \\
\text { - } \\
\text { a research fellow at Tel Aviv University's Moshe Dayan Center for Middle Eastern and African Studies } \\
\text { also teaches modern North African history at the university's Department of Middle Eastern and African } \\
\text { History and at the Hebrew University's Rothberg International School } \\
\text { born in the U.S. and has lived in Israel since childhood } \\
\text { Israel educated }\end{array}$ \\
\hline
\end{tabular}


Table 8: University of Nebraska, Omaha, Schwalb Center for Israel \& Jewish Studies

\begin{tabular}{|c|c|c|c|}
\hline \multicolumn{2}{|c|}{\begin{tabular}{|l|l|} 
No & Course \\
\end{tabular}} & \multirow{2}{*}{\begin{tabular}{|l|} 
Instructors \\
Rami Arav
\end{tabular}} & \multirow[b]{2}{*}{\begin{tabular}{|l} 
Positions and Education \\
$-\quad$ was affiliated with the Golan Research Institute associated with Haifa University \\
$-\quad$ Director of Excavations \\
Bethsaida Excavations Project (includes 20 universities and colleges worldwide \\
housed at \\
the University of Nebraska at Omaha) \\
$-\quad$ teaches in the Department of History and the Department of Philosophy and \\
$\quad$ Religion at UNO \\
Israeli born, served in Israeli army, Israeli and American educated (PhD from \\
New York University)
\end{tabular}} \\
\hline 1 & $\begin{array}{l}\text { Archeology of Biblical } \\
\text { Lands }\end{array}$ & & \\
\hline 2 & $\begin{array}{l}\text { Egyptian and Babylonian } \\
\text { Religion }\end{array}$ & Rami Arav & - \\
\hline 3 & Biblical Archeology & Rami Arav & - \\
\hline 4 & Israel and Palestine & $\begin{array}{l}\text { Moshe } \\
\text { Gershovich }\end{array}$ & $\begin{array}{l}\text { Professor, Director, Natan \& Hannah Schwalb Center for Israel \& Jewish } \\
\text { Studies } \\
\text { teaching career started at MIT 1995-1998. Then he taught two and a half years } \\
\text { at Al-Akhawayn University in Ifrane, Morocco. In 2001, he started teaching at } \\
\text { UNO. } \\
\text { Israeli born, Israel and American educated (PhD from Harvard) } \\
\end{array}$ \\
\hline 5 & Women and the Bible & Curtis Hutt & $\begin{array}{l}\text { - } \quad \text { Assistant professor and Special Programs Coordinator Schwalb Center } \\
\text { moderator of the Middle East Forum (of UNO) and also serves on the faculty } \\
\text { advisory board of Islamic Studies } \\
\text { spends summers in Jerusalem where he spends time working with local and } \\
\text { international scholars } \\
\text { American educated }\end{array}$ \\
\hline 6 & Middle East politics & $\begin{array}{l}\text { Ramazan } \\
\text { Kilinc }\end{array}$ & $\begin{array}{l}\text { the Director of Islamic Studies Program } \\
\text { Turkish and American educated }\end{array}$ \\
\hline 7 & $\begin{array}{l}\text { Government and Politics } \\
\text { of the Middle East }\end{array}$ & $\begin{array}{l}\text { Ramazan } \\
\text { Kilinc }\end{array}$ & \\
\hline 8 & $\begin{array}{l}\text { Introduction to Russian } \\
\text { Literature }\end{array}$ & \begin{tabular}{|l|l|} 
Tatyana \\
Novikov
\end{tabular} & \begin{tabular}{|ll}
- & It is unclear what relation this course has to Israel studies!!!! \\
& American educated
\end{tabular} \\
\hline
\end{tabular}

Table 9: The Schusterman Center for Jewish Studies, College of Liberal Arts, The University of Texas at Austin ${ }^{15}$

\begin{tabular}{|c|c|c|c|}
\hline \multicolumn{2}{|c|}{ No Course } & \multirow{2}{*}{\begin{tabular}{|l|} 
Name \\
Erga Atad
\end{tabular}} & \multirow[b]{2}{*}{\begin{tabular}{|l} 
Education and positions \\
$-\quad$
\end{tabular}} \\
\hline 1 & $\begin{array}{l}\text { Arab-Israeli } \\
\text { Conflict }\end{array}$ & & \\
\hline 2 & $\begin{array}{l}\text { Israel: Society \& } \\
\text { Politics }\end{array}$ & $\begin{array}{l}\text { Joseph } \\
\text { Paritzky }\end{array}$ & 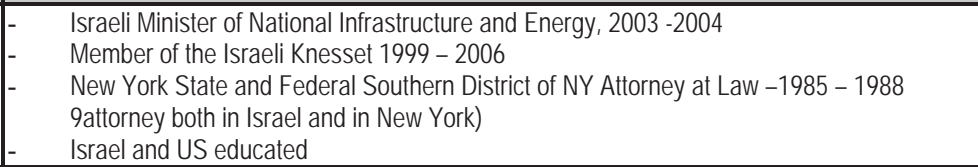 \\
\hline 3 & Multicultural Israel & $\begin{array}{l}\text { Amelia } \\
\text { Weinreb }\end{array}$ & $\begin{array}{l}\text { American educated, post-doc at Ben-Gurion University, Israel Jacob Blaustein Institute for } \\
\text { Desert Research }\end{array}$ \\
\hline 4 & $\begin{array}{l}\text { State and Religion } \\
\text { in Israel }\end{array}$ & $\begin{array}{l}\text { Joseph } \\
\text { Paritzky }\end{array}$ & \\
\hline 5 & $\begin{array}{l}\text { Policymaking in } \\
\text { Israel }\end{array}$ & $\begin{array}{l}\text { llana } \\
\text { Speizman }\end{array}$ & $\begin{array}{ll}- & \text { Director of The Israeli Agendas Project } \\
- & \text { Schusterman grant for Israeli Studies, University of Texas at Austin } \\
- & \text { Lecturer at the Hebrew University of Jerusalem, 2012-2014 } \\
- & \text { American born, Israeli educated, post-doc at University of Texas at Austin }\end{array}$ \\
\hline
\end{tabular}

15 http://www.israelstudies.org/courses.html 
Table 10: University of Colorado, Boulder, Program in Jewish Studies ${ }^{16}$

\begin{tabular}{|c|c|c|c|}
\hline No & Course & Instructor & Education and positions \\
\hline 1 & The Bible as Literature & Sue Zemka & \\
\hline 2 & Representing the Holocaust & Davide Stimilli & \\
\hline 3 & Biblical Hebrew & Zilla Goodman & $\begin{array}{l}\text { - Senior Instructor, Coordinator of the Hebrew Language and } \\
\text { Literature Program, and Director of Undergraduate Studies for } \\
\text { the Program in Jewish Studies }\end{array}$ \\
\hline 4 & Beginning Hebrew 1 & ( 2 courses) & \\
\hline 5 & Intermediate Hebrew 1 & & \\
\hline 6 & $\begin{array}{l}\text { Third Year Hebrew, First } \\
\text { Semester }\end{array}$ & Eyal Rivlin & \\
\hline 7 & Hebrew Independent Study & Zilla Goodman & \\
\hline 8 & $\begin{array}{l}\text { Topics in Hebrew Studies: } \\
\text { Radical Jews }\end{array}$ & Zilla Goodman & \\
\hline 9 & $\begin{array}{l}\text { Honors: Introduction to } \\
\text { Jewish History: Since } 1492\end{array}$ & Liora Halperin & Assistant Professor of History and Jewish Studies \\
\hline 10 & $\begin{array}{l}\text { Decolonization of the British } \\
\text { Empire }\end{array}$ & Lucy Chester & Associate Professor of History and International Affairs \\
\hline 11 & $\begin{array}{l}\text { History of Modern Jewish- } \\
\text { Muslim Relations }\end{array}$ & Liora Halperin & \\
\hline 12 & $\begin{array}{l}\text { Nazi Germany and the } \\
\text { Holocaust }\end{array}$ & David Ciarlo & Associate Professor of History \\
\hline 13 & Internship in Jewish Studies & Nan Goodman & $\begin{array}{l}\text { Director of the Program in Jewish Studies, Professor of English } \\
\text { and Jewish Studies }\end{array}$ \\
\hline 14 & $\begin{array}{l}\text { Independent Study in Jewish } \\
\text { Studies }\end{array}$ & $\begin{array}{l}\text { Jewish Studies } \\
\text { Faculty }\end{array}$ & \\
\hline 15 & Judaism & Elias Sacks & 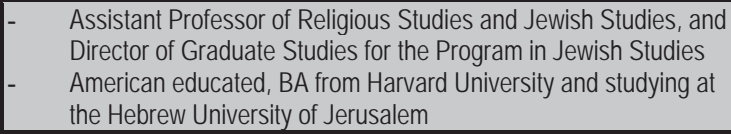 \\
\hline 16 & $\begin{array}{l}\text { Women, Gender, and } \\
\text { Sexuality in Judaism }\end{array}$ & Zilla Goodman & \\
\hline 17 & $\begin{array}{l}\text { Magic in Judaism and } \\
\text { Christianity }\end{array}$ & Sam Boyd & American educated \\
\hline 18 & $\begin{array}{l}\text { Love and Desire in Judaism } \\
\text { and Christianity }\end{array}$ & Elias Sacks & \\
\hline 19 & After the Holocaust & Corie Rosen Felder & \\
\hline
\end{tabular}

The following Universities do not provide list of Fall 2015 courses on Israel Studies ${ }^{17}$ : Emory University's Institute for the Study of Modern Israel, Cal State University, Chico, Modern Jewish \& Israel Studies, and the University of Denver's Institute for the Study of Israel in the Middle East, and Yeshiva University's Center for Israel Studies.

\subsubsection{The Instructors}

Information on the professors who teach these courses (including their current position, education, and previous academic and political activities) has also been provided in the fourth column of the tables. As this data demonstrates, nearly all instructors of such courses have had at least some experience inside Israel. Some of them are visiting scholars and others are resident in America. Some American scholars have been trained through programs such as the Schusterman Center for Israel Studies at Brandeis University's Summer Institute for Israel Studies (SIIS) ${ }^{18}$. A handful of professors have no personal connection at all with Israel but this is the exception rather than the rule. Some of Israel

${ }^{16}$ http://www.colorado.edu/jewishstudies

17 The complete list of universities with Israel studies programs obtained from Jewish Virtual Library at: http://www.jewishvirtuallibrary.org/jsource/isdf/centers.html

18 The author was unable to find the names of the scholars who have participated in SIIS, but information on the program is available on the Brandeis University website at: http://www.brandeis.edu/israelcenter/SIIS/, and Koren's report entitled The Summer Institute for Israel Studies 2004-2012. 
studies scholars are not active only in Israel studies programs but teach other courses at other faculties as well.

According to tables 2-10 that demonstrate the scholars teaching Israel studies courses, these scholars can be categorized into several groups. This categorization is based on the ways that keep them simultaneously linked to both America and Israel:

1. Israeli scholars who have received part of, or all their education in American universities.

a. Mostly this consists of individuals who have completed their BA and MA in Israel, then moved to the US for PhD or post-doc and have remained and obtained teaching positions in American Universities.

2. Israeli scholars who have been educated in Israel, but come to American campuses through visiting professor programs, or are invited to give speeches. This consist of:

a. Scholars who go back after their term as visiting professors is finished

b. Scholars who stay in the US and receive permanent academic positions in American universities

3. American scholars who have maintained link with Israel because of their Jewish identity, and through visits and connections.

4. Scholars who have had non-academic working experience (political activity, for example) in both one or both societies:

a. Those who, irrespective of the place they were educated, have working experience (non-academic) in both societies (Ori Aronson, for example, has "served as a law clerk to Israeli Supreme Court Chief Justice, Aharon Barak, as well as to Judge Jon O. Newman (United States Court of Appeals, Second Circuit)")

b. Scholars who have experienced a political career in either US, Israel or both .These include Israeli Diplomats or politicians, who are now absorbed by American universities because of their experience rather than academic background. An example is Dan Arbell (No. 3 Table 4).

Many of these individuals have a truly dual life, meaning that their experience with Israel is not confined to several years of education there. They constantly move back and forth, are present in institutions of both societies either simultaneously or in consecutive time periods. Yehudah Mirsky (no. 8 in table 2) is a perfect example. He is also a case of Israeli educated individuals who have had experience in the American government and politics (meaning that this concept of dual identity is not limited to the realm of academia).

Many scholars are an amalgam of all or some of the mentioned categories and cannot be confined to one group. Yoram Peri, for example, was educated in the UK, has had political and academic activity in Israel, been member of American think tanks, and now serves as the Director, Joseph and Alma Gildenhorn Institute for Israel Studies.

Such scholars can be regarded as having dual identities. Dual identity scholars are defined as individuals who get to experience the academic and political environment both in Israel and America, and contribute to academic discourse (in many instances in both Hebrew and English) in both societies through the classes they teach and literature they produce. These people have internalized aspects of both cultures, and will help construct we-feeling between the two. The fact that there are individuals who can freely and easily fluctuate between American and Israeli universities, think tanks and political positions is itself evidence to the claim that the two identities are moving closer,

An important characteristic of Israeli originated scholars (who sometimes have political activities inside America as well) is that they strongly retain their Israeli identity and link to the Israeli society and even political system. This means that their group identity is salient, so, according to contact theory, reduction of prejudice towards these individuals will generalize to the whole Israeli entity.

\subsubsection{Visiting professors}

One of the most important methods used by Israel advocates in order to "weave Israel into the tapestry of the American academy" (Weiss, 2013) is to bring Israeli scholars to teach and speak in American universities. Whilst some universities use a combination of visiting and American professors, there are instances like the Emory University's Institute for the Study of Modern Israel where there are no permanent faculty members and all instructors are visiting professors from Israel ${ }^{19}$.

Ilan Troen and Ron Zweig are named as two influential Israeli scholars brought to American universities to hold Israel studies chairs (Shenkar, 2010). On the other hand, visiting professors are not limited to teaching Israel studies courses and programs, or to Israel studies centers and faculties. They are distributed across different faculties(such as history, English, etc.) and sometimes teach other, more general courses. The Israel Studies website states that funded

19 http://ismi.emory.edu/home/visiting-scholars/index.html 
scholars are required to teach four courses, at least two of which should be related to "modern Israel" (meaning that the other two could be totally unrelated to Israel) ("About the VIP Program,"). Uri Bialer, visiting professor at Brandeis, for example, teaches at both the Department of History and the Near Eastern and Judaic Studies program, whilst both his courses are related to Israel. Yoram Peri, whilst being Director of the Joseph and Alma Gildenhorn Institute for Israel Studies, is an affiliate faculty member at the department of Education at the University of Maryland.

This approach of distributing visiting professors among different departments and allowing them to teach courses other than Israel-focused ones has the obvious outcome of the Israeli perspective being represented in different fields. In the case of Political Science/International Relations and issues generally related to the domestic and international policies of Israel (whether it be the conflict with Palestinians or other issues), visiting professors are a channel through which the Israeli side of the story is presented to American students. Critics might argue that visiting Israeli professors are not representatives of the Israeli government; they are free thinking academicians and are not biased but have an objective stance towards their field of study. To answer this criticism, two points need to be highlighted. First, visiting professors are financed through pro-Israel centers; organizations that openly state support of Israel and promotion of a positive image of that regime as their goals. Certainly they would not spend large sums of their budgets annually for bringing Israeli professors to America if it did not conform to their stated goals. Reports evaluating Israel's profile on American campuses also widely suggest bringing Israeli scholars as a way of creating a more Israel friendly atmosphere on campus (see (Coalition, 2007) and (Koren \& Einhorn, 2010)).

The second point is that the presence of objective looking scholars, who analyse and even criticize Israeli policies (and not the existence and legitimacy of Israel) with an unbiased, scientific and critical approach, is itself a latent method of promoting the regime. Such professors serve to convince American students that Israel belongs to their own ingroup; legitimate but not flawless.

Another outcome of bringing Israeli scholars is to present a scientific, developed, and altogether positive image of Israel through scholars who are Israeli citizens. It demonstrates that Israel is capable of producing leading experts in all scientific fields, and thus is a contributing member of the Western world. It not only conforms to Western ideals but also is a leading member that can benefit others as well.

In some instances the visiting Israeli professor programs are jumping boards for Israeli scholars, through which they get known in the American academic environment, and so are invited to give speeches, or even serve as permanent faculty members in the future. Although some funders insist that in order to prevent a "brain drain from Israel", scholars should return when their visit, which could be a maximum of three academic years, ends ${ }^{20}$, but this does not always happen. Arie Perliger, for example, who is now the director of Terrorism Studies at the Combating Terrorism Center and Associate Professor at the Department of Social Sciences, US Military Academy at West Point, is an Israel educated scholar who was a Schusterman Visiting Assistant Professor from 2008-2010.

Not being confined to the classroom for expressing one's opinions and views, and utilizing other forms of presentation is not limited to visiting artists. Many visiting professors use the opportunity of being in the US to give speeches and lectures on different subjects. Koren and Einhorn classify these activities as on campus (e.g., providing lectures in their host universities, meeting other faculty members and student activists) and off campus (e.g., participation in seminars and workshops and giving guest lectures in other universities throughout the US) extracurricular activities (2010).

Israel is introduced as being just like any other state, like America itself; it has its flaws and mistakes but it is on the right track nevertheless. Visiting professors do their best to appear unbiased and objective; they might not directly discuss who's to blame in the conflict, but through introducing the sophistication of Israeli society and politics, presenting its institutions which resemble American ones, and also providing unofficial personal stories, internalize a "we feeling" in their students. Dr. Aviad Raz, visiting professor at UC San Diego, for example, talks to his class about his two son's experience in the IDF, and also about how classes are cancelled in Ben-Gurion University so students can take cover during missile attacks (M. Bard, 2013a).

\subsubsection{Institutions and Funders}

The American-Israeli Cooperative Enterprise (AICE) is one of the main organizations active in promoting academic contact between America and Israel, although its activities are not limited to this endeavour. The organization was established in 1993 as a nonprofit and nonpartisan organization to "strengthen the U.S.-Israel relationship by

${ }^{20}$ http://www.israel-studies.com/vips 
emphasizing the fundamentals of the alliance - the values our nations share"21. AICE has founded the Israel Scholar Development Fund (ISDF) to "address the critical need to develop new scholars and place established Israel scholars on campus"22. The ISDF identifies American and Israeli professors whom it sees suitable for visiting professorship programs, funds universities to hire these scholars, and identifies "institutions that could and should have pro-Israel scholars"23. The main funding for AICE's visiting professors comes from the Charles and Lynn Schusterman Family Foundation, which sponsors the annual Schusterman Visiting Israel Professors (VIP) program ${ }^{24}$. The Israel Institute is another organization active in this field, which sponsors exchange programs in the form of its Faculty Exchange Program and Teaching Fellows Program 25 .

As the names of the Israel studies centers in Tables 2-10 demonstrate, most centers are founded and funded by family foundations. This is very important, and one of the reasons why the discipline has been able to strive through the economic hardship that has made funding new programs and courses difficult for universities. Koren has also highlighted the importance of "external funding" for the field (Koren \& Fishman, 2015)

Other than institutions and funds that help sustain Israel studies economically, there are organizations that help link scholars in the discipline through diverse means such as holding conferences and meetings. The role of academic journals as meeting places of ideas is also important. Shenkar points to the relationship between the development of disciplines such as American studies and Israel studies with the emergence of association and academic journals (Shenkar, 2010). The Association for Israel Studies is the main example here. It was founded in 1985, and is introduced as an international organization, but all of its institutional members are American universities, and its board of directors consists of American and Israeli individuals. Ilan Troen is the President of the association. Troen is also founder and editor of the Israel Studies journal ${ }^{26}$. Israel Studies Review is the journal published by the Association for Israel Studies and is edited by Yoram Peri'27.

\section{Conclusion}

It should be noted that the current research is not a testing of contact theory, but an attempt to demonstrate that Israeli advocate's academic endeavor fits well into the theory's prescriptions for improving intergroup relations, and also goes a few steps further. Whilst in the usual settings where contact theory is tested, the situation is designed to allow contact between two groups who do not intentionally aim to fight prejudice and are placed in the situation by scholars aiming to study the outcomes, in the case studied here the pro-Israel individuals and institutions that are involved in contact are aware of the overall goal of bettering the understanding of Israel inside American universities and amongst educated Americans.

What is apparent when comparing the public and academic discourse on Israel in the US is the fact that constructing a positive image is a much more manifest process in the public and political arena whilst it is latent, sophisticated and multifaceted in academic spheres. This seems natural given the more nuanced and critical approach that academicians have. Israel faces more challenges in universities where people tend to be more informed on international issues than the general public. So in classrooms, simple rhetoric won't work, and what is needed instead is deeper analysis. All this necessitates a different and special Israel advocacy approach in the universities; what is deemed here as academic contact. So the trend seen in Israel studies courses is one in which instead of trying to portray Israel as justified in every aspect, an attempt is made at normalizing and naturalizing the regime.

It is widely accepted that ignorance breeds prejudice, and Israel advocates and interest groups have actively been fighting ignorance-based prejudice. Establishing Israel studies programs and courses across the country, bringing Israeli professors to American classrooms, taking American professors to experience the Israeli academic environment, are some of the methods applied by Israel advocates to overcome such ignorance through promoting contact between the two people, and ultimately generating a sense of we-feeling between Israelis and Americans. All of these attempts promote positive contact between the American and Israeli academic worlds (encompassing students, professors and the whole university campus), which is intended to not only overcome prejudice, but to go one step further and establish the commonality of American and Israeli identity, whilst simultaneously constructing Israel as a member of the Self that also

\footnotetext{
${ }^{21}$ http://www.jewishvirtuallibrary.org/about/index.shtml

22 Ibid

${ }^{23} \mathrm{Ibid}$

${ }^{24}$ http://dev.jewishvirtuallibrary.org/cgi-bin/itemPrintMode.pl?/d=17780

25 http://www.israelinstitute.org/programs/visiting-israeli-professors

${ }^{26}$ http://www.brandeis.edu/israelcenter/publications/journal/

${ }^{27}$ http://journals.berghahnbooks.com/israel-studies
} 
has distinct positive and normal characteristics, which demands respect and recognition.

As mentioned earlier, learning about the outgroup, changing behavior, generating affective ties, and ingroup reappraisal are the four processes through which contact eliminates prejudice. Of these, the first and third cases are explicitly evident in the case of Israel studies. The whole idea of promoting Israel studies in American universities is to teach Israel to Americans, from an Israeli perspective (especially where instructors are brought over from Israel). Affective ties are also generated when Israeli professors interact with American students in formal and non-formal situations. In some instances professors open up and start narrating personal accounts of life in Israel. So an Israeli professor who looks completely American and normal and speaks in perfect English (decategorization) is brought to a campus to teach for a limited number of semesters. After establishing a firm relationship with students, he begins to discuss his distinct experience and life as an Israeli (salient categorization), for example the worries and hardship of having a son who is serving in the IDF. (M. Bard, 2013b)

But the study of Israel studies as a discipline and its instructors demonstrates that intergroup relations are improved not only through actual interpersonal contact, but also through the presentation and dissemination of a certain type of knowledge by outgroup members who are representative of their group. So it is not just the presence of an Israeli professor in a classroom and his contact with students (as an instructor and as a human being), which is crucially important, but his books, articles and overall contribution to the academic discourse that will affect the way Israel is viewed in America, not just through providing knowledge on Israel, but also through attempting to define more general concepts, problems and solutions for the educated audience. The latter function also has the effect of presenting Israel as able to tackle more universal issues and to contribute to the advancement of knowledge in general, and also to present Israel's worldview as logical and scientific (just like the Self). Thus, learning about the world should be added to Pettigrew's four processes of improving intergroup relations through contact. This is not a general addition to contact theory, but one specific to the case of academic contact between America and Israel (which could be used by other entities as well), suggesting that this contact leads to not just a common identity and we-feeling between the two, but that through a forceful presence on the academic scene, Israeli scholars also get to define what the common values of the two groups are. This, together with the mentioned fact that in the academic context, contact can happen not only between individuals, but also between ideas and thoughts, distinguish this type of contact from other versions, and qualify it to be designated as a new concept called academic contact.

\section{References}

Bard, M. (2008). Israel Studies Grows on Campus. from http://www.jewishpolicycenter.org/460/israel-studies-grows-on-campus

Bard, M. (2013a). Israeli Professors On Teaching in America. Retrieved from http://blogs.jpost.com/content/israeli-professors-teachingamerica

Bard, M. (2013b). Israeli Professors On Teaching in America. Retrieved 28 december, 2015, from http://www.jpost.com/Blogs/Classroom-Battlegrounds/Israeli-Professors-On-Teaching-in-America-364174

Bard, M. G. (2004). Tenured or Tenous: Defining the Role of Faculty in Supporting Israel on Campus.

Blander, D. (2010). Democracy in Theory and Israel in Practice [Syllabus]. Tufts University. A Burning Campus? Rethinking Israel Advocacy at America's Universities and Colleges. (2012): The David Project.

Coalition, T. I. 0. C. (2007). In Search of Israel Studies: A Survey of Israel Studies on American College Campuses: The Israel on Campus Coalition (ICC).

Ellemers, N., \& Haslam, S. A. (2012). Social Identity Theory. In P. A. M. V. Lange, A. W. Kruglanski \& E. T. Higgins (Eds.), Handbook of Theories of Social Psychology: Volume Two (Vol. 2): SAGE Publications.

Epstein, A. D. (2004). The Current Sociological Agenda of Israel Studies in Israel/USA and Russia: a Reexamination. Israel Studies Forum, 19(3), 83-98.

Gaertner, S. L., Rust, M. C., Dovidio, J. F., Bachman, B. A., \& Anastasio, P. A. (1994). The Contact Hypothesis:The Role of a Common Ingroup Identity on Reducing Intergroup Bias. Small Group Research, 25(2), 224-249.

Gagnon, Y.-C. (2010). The Case Study as Research Method: A Practical Handbook: PUQ.

Gerring, J. (2007). The Case Study: What It Is and What It Does. In C. Boix \& S. C. Stokes (Eds.), The Oxford Handbook of Comparative Politics: Oxford University Press.

Gullahorn, J. T., \& Gullahorn, J. E. (1960). The Role of The Academic Man as A Cross-Cultural Mediator. American Sociological Review, 25(3), 414-417.

Koren, A., \& Einhorn, E. (2010). Expanding the Study of Israel on Campus: The American-Israeli Cooperative Enterprise 2005-09: Brandeis University Maurice and Marilyn Cohen Center for Modern Jewish Studies

Koren, A., \& Fishman, S. (2015). Israel Studies Directory: 2013-14 Report Update: Brandeis University Maurice and Marilyn Cohen Center for Modern Jewish Studies.

Koren, A., \& Fleisch, E. (2014). 2012-13 Israel Studies Report and Directory: Brandeis University Maurice and Marilyn Cohen Center for Modern Jewish Studies. 
Koren, A., Samuel, N., Aronson, J. K., Saxe, L., Aitan, E., \& Davidson, J. (2013). Searching for the Study of Israel: A Directory of Courses about Israel on U.S. College Campuses 2011-12: Brandeis University Maurice and Marilyn Cohen Center for Modern Jewish Studies.

Koren, A., Samuel, N., Boxer, M., \& Aitan, E. (2013). Teaching and Learning about Israel: Assessing the Impact of Israeli Faculty on American Students: Brandeis University Assessing the Impact of Israeli Faculty on American Students.

Peri, Y. (2008). Israeli Democracy at 60: Achievements and Challenges [syllabus]. American University.

Pettigrew, T. F. (1998). Intergroup Contact Theory. Annual Review of Psychology, 49(1), 65-85

Shenkar, M. (2010). The Politics of Normalization: Israel Studies in the Academy. (Doctor of Philosophy), The Ohio State University.

Spears, R., \& Tausch, N. (2012). Prejudice and Intergroup Relations. In M. Hewstone, W. Stroebe \& K. Jonas (Eds.), An Introduction to Social Psychology: John Wiley \& Sons.

Weiss, P. (2013). At a campus near you: an Israeli artist-in-residence, here 'to teach'. Retrieved 7 January, 2014, from http://mondoweiss.net/2013/09/at-a-campus-near-you-an-israeli-artist-in-residence-here-to-teach.html

Yin, R. K. (2006). Case Study Methods. In J. L. Green, G. Camili \& P. B. Elmore (Eds.), Handbook of Complementary Methods for Research in Education: The American Educational Research Association.

Yin, R. K. (2009). Case study research: design and methods (fourth ed.): Sage. 